Ann. Biol. anim. Bioch. Biophys., 1978, 18 (2 B), 419-426.

\title{
Interrelationships between the oocyte and somatic cells within the Graafian follicle of mammals
}

\author{
by T. G. BAKER $\left({ }^{1}\right)$, R. H. F. HUNTER * \\ Department of Obstetrics and Gynaecology \\ * School of Agriculture, University of Edinburgh, U. K.
}

Summary. Factors involved in the maturation of the oocyte and especially in the resumption of meiosis following the pre-ovulatory surge of gonadotrophin have been reviewed for a number of mammals. Follicular size has been shown to be an important physiological regulator of meiotic potential in several species, although when the oocytes are released into a chemically defined culture medium the influence of follicular diameter may be lost and meiosis can resume spontaneously in a high proportion of oocytes. Turning to studies of Graafian follicles in culture, a contrast was drawn between the requirements for meiotic maturation in oocytes of laboratory rodents and those in larger domestic species and women : gonadotrophins and added steroids seem necessary to facilitate maturation in the latter group. This finding is in accord with recent work on a porcine experimental model in which the process of HCG-induced ovulation can be dissociated from nuclear, cytoplasmic and membranous components of oocyte maturation when oestrogen concentrations in the follicular fluid are « low ». However, the precise mode of action of intra-follicular cestrogens on the somatic cells (and on the oocyte ?) remains to be clarified. A possible involvement of prolactin in these follicular events is also considered.

\section{Introduction.}

The female mammal is born with a finite sfock of germ cells which reach the diplotene (arrested) stage of meiotic prophase either by the time of, or shortly after birth (e.g. see Baker, 1971). Irrespective of age or the stage of the reproductive cycle, about 90 p. 100 of these arrested oocytes are enclosed within primordial follicles consisting of a single layer of granulosa cells. The early stages of follicular growth are independent of gonadotrophic support, although the precise regulatory processes involved remain obscure (Zuckerman and Baker, 1977). The subsequent development of the antral follicle requires an adequate supply of follicle stimulating hormone (FSH) followed by the trophic influence of luteinizing hormone (LH). These hormones cause the expansion of the antrum and maturational changes in the theca and granulosa cells, although the oocyte nucleus remains morphologically unaffected until the onset

(1) Address for correspondence : Dr T. G. Baker, Hormone Laboratory, Department of Obstetrics \& Gynaecology, 23 Chalmers Street, Edinburgh EH3 9EW, United Kingdom. 
of the so-called " LH-surge ". FSH and LH - either directly or indirectly through steroid intermediates (especially œstrogen) - also regulate the proportion of follicles which undergo ovulation or atresia (e.g. Harman et al. 1975 ; Hay and Cran, 1978).

There can be little doubt that the onset of pre-ovulatory maturation of the oocyte and its follicle in vivo is related to the "LH-surge", although the precise sequence of events that follows this stimulus remains to be established. The purpose of the present communication is to discuss the available experimental evidence derived largely from studies of rodent, sheep, pig and primate follicles both in vivo and in organ culture.

\section{Evidence from in vivo studies}

The period of meiotic arrest at the diplotene stage of first prophase persists until a time (which is constant for each species) shortly before ovulation when a surge of gonadotrophic hormones induces germinal vesicle breakdown (GVB) (table 1). It should be noted, however, that gonadotrophins are only required when the oocyte resides within its follicle : when oocytes are removed into a chemically defined medium they resume meiosis spontaneously to metaphase II (but see below).

TABLE I

Time-response in hrs of the oocyte nucleus to the LH surge or a systemic injection of LH/HCG

\begin{tabular}{|l|c|c|c|c|c|c|}
\hline Species & \multicolumn{1}{|c|}{$\mathrm{M}_{1}$} & $\mathrm{~A}_{1}$ & $\mathrm{~T}_{1}$ & $\mathrm{M}_{2}$ & Ovulation \\
${$\cline { 4 - 8 }$} }$ & After Stimulus & & & & & \\
\hline \hline Rabbit & $3-4$ & $5-8$ & 9 & $91 / 2$ & 10 & $10-12$ \\
\hline Sheep & $10-11$ & $12-20$ & 21 & 22 & 24 & $25-26$ \\
\hline Pig & $17-18$ & $26-34$ & 35 & 36 & 37 & $40-42$ \\
\hline Human & $18-20 ?$ & $25-35$ & 36 & 37 & 38 & $40 ?$ \\
\hline
\end{tabular}

It is well established that the pre-ovulatory "surge " of gonadotrophins above the tonic values found in plasma during the rest of the reproductive cycle consists of both FSH and LH, although the levels of LH are by far the highest (e.g. Speroff and Vande Wiele, 1971 ; Schwartz, 1974). Yang and Papkoff (1973) have shown that PMSG, HCG, FSH and LH can all induce ovulation in intact rats, and the activity of 
FSH in this context is not due to contamination with $\mathrm{LH}$ : treatment of $\mathrm{LH}$ with antiserum to the $\beta$-sub-unit of $\mathrm{LH}$ abolishes its effect on oocyte maturation and ovulation whereas the influence of FSH remains unaffected by this antiserum (Yang and Papkoff, 1973 ; Lindner et al., 1974).

The effect of treatment with gonadotrophins on pre-ovulatory maturation in mice is dependent upon the size of the follicle. The stage of meiosis attained by the oocyte varies from germinal vesicle stage (pre-antral and abnormally large Graafian follicles) through metaphase or anaphase I (small antral follicles) to metaphase II (only when the oocyte resides in a mature Graafian follicle) (Baker and Neal, 1972). When oocytes are removed from their follicles into chemically defined media, the oocyte resumes meiosis only if it is derived from an antral follicle (e.g. Sorensen and Wasserman, 1976). This implies that the follicle undergoes a process of maturation which affects the ability of its oocyte to undergo meiosis.

Further evidence for the maturation of somatic components of the follicle influencing the oocyte derives from an experiment in which mature pigs were injected with HCG either on the day preceding the « LH-surge » (day 20 of the cycle), or when the follicle is much smaller and immature (day 17). Injection of HCG on day 20 results in the ovulation of normal oocytes at metaphase II which, when exposed to spermatozoa, show the normal block to polyspermy and full development of a single male and female pronucleus. By contrast, injection of pigs on day 17 of the 21 day œstrous cycle induces ovulation of immature eggs at the germinal vesicle stage : these oocytes

\section{RESPONSE TO A SINGLE INJECTION OF GONADOTROPHIN IN EARLY OR LATE FOLLICULAR PHASE}

500 i.u.

OESTRUS -

OESTRUS +
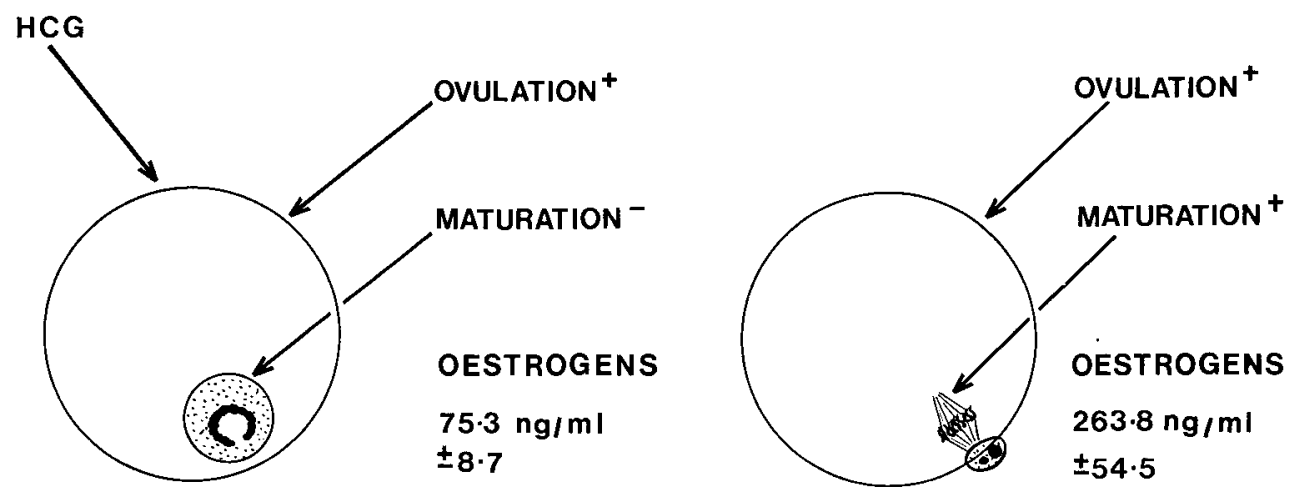

\section{DAY 17} TREATMENT

\section{DAY 20}

\section{TREATMENT}

FIG. 1. - A semi-diagrammatic illustration of ovarian and behavioural responses of mature pigs to a single injection of HCG given af different times of the oestrous cycle. Animals treated on day 17 ovulate in response to the injection, but the oocytes so released are completely immature (see text), the animals fail to show oestrus (lordosis), and the concentration of oestrogens in the follicular fluid is depressed compared with that following treatment on day 20 (After Hunter ef al., 1976.) 
show no block to polyspermy, sperm heads in the vifellus do not swell to form male pronuclei, and the cumulus cells remain immature and spherical in shape (Hunter, Cook and Baker, 1976). The immaturity of the follicles on day 17 of the cycle is not confined to the size of the follicle and the shape of cumulus cells : the concentrations of œstrogens in follicular fluid are only one third of those in control animals or those injected with HCG on day 20 (fig. 1). Thus these results show clearly that there are a number of cellular and endocrine events occurring simultaneously in the follicle during pre-ovulatory maturation, only one of which is the resumption of meiosis in the oocyte (fig. 1).

\section{Maturation of Graafian follicles in organ culture}

Studies of isolated mouse ovaries, or of rat Graafian follicles treated in vitro, have clearly indicated that both FSH and $\mathrm{LH}$ can induce pre-ovulatory maturation of the follicle, although in the absence of these supplements to the culture medium, resumption of meiosis in oocytes is a rare event (Baker and Neal, 1972 ; Lindner et al., 1974). Indeed, FSH is more effective than $\mathrm{LH}$ (Neal and Baker, 1975) and a number of substances can mimic the action of gonadotrophins (prostaglandin E2, PGF2 $\alpha$, cyclic AMP, efc..., but not prolactin : see Lindner et al., 1974 ; Neal ef al., 1975, 1976 ; McNatty et al., 1976). It is often suggested that steroid hormones are the intermediates affecting the oocyte or its cumulus oophorus (Schuetz, 1977), although there is evidence that steroids do not have to be produced in response to the « LH-surge » since aminoglutethimide and cyanoketone do not block LH-induced oocyle maturation (Lindner ef al., 1974). The possibility remains, however, that the high levels of steroids in the follicle prior to the "LH-surge » are sufficient to act as intermediates without the necessity for further steroid synthesis (Baker ef al., 1977).

By contrast, neither FSH nor LH seem to be able directly to induce the resumption of meiosis in oocytes within sheep, pig or human Graafian follicles maintained in organ culture (Baker and Neal, 1974 ; Hay and Moor, 1975 ; Baker et al., 1975 ; Biggs, Baker and Hutcheon, 1977). It seems likely, therefore, that the physiological requirements for oocyte maturation in these species may be somewhat different to those in rodents and lagomorphs (see above; also Thibault et al., 1975). The lack of an in vitro action of gonadotrophins in ungulates and primates may be due to an inadequate number of binding sites since prostaglandin E2 (which like LH acts on the adenyl cyclase system) can induce the resumption of meiosis in follicle-enclosed porcine oocytes (table 2). However, cyclic-AMP itself was without effect and it is more difficult to explain the action of prostaglandin $F 2 \alpha$ (table 2 ).

In porcine and ovine Graafian follicles maintained in organ culture, meiotic maturation of oocytes can be induced if $\mathrm{FSH}, \mathrm{LH}$ and œstradiol-17 $\beta$ are administered simultaneously (Moor and Trounson, 1977 ; see also table 2). There can be no doubt that the $\mathrm{LH}$ component is required for steroidogenesis although the FSH may promote the formation of suitable binding sites in the granulosa cells. Whether it is the FSH or LH which " triggers 》 the resumption of meiosis within the oocyte remains uncertain, although it is tempting to draw parallels with the results for mouse follicles (see above). The precise role of follicular œstrogen is also obscure : it is conceivable that it is an intermediate and augments the action of the FSH or $\mathrm{LH}$ in the culture 
system : or it may compensate for an inadequate synthesis of steroid by the follicle in vitro. It is interesting to note that high levels of cestradiol-17 $\beta$ are found in the antral fluid of human Graafian follicles in vivo (McNatty ef al., 1975), although the levels decline shortly before the onset of the «LH-surge » when progesterone is accumulated in the fluid.

TABLE 2

Stage of meiosis aftained following treatment of pig Graafian follicles * in organ culture ** with various hormones. Oocytes were recovered $24-48 \mathrm{~h}$ after onset of culture and examined with phase contrast optics ***

\begin{tabular}{|c|c|c|c|c|c|c|}
\hline $\begin{array}{l}\text { Stage of } \\
\text { cycle }\end{array}$ & $\begin{array}{l}\text { Number } \\
\text { of animals }\end{array}$ & Treatment & $\begin{array}{l}\text { Nuclear status } \\
\text { at onset of } \\
\text { culture }\end{array}$ & $\begin{array}{l}\text { No follicles } \\
\text { cultured }\end{array}$ & $\begin{array}{l}\text { No. oocytes } \\
\text { recovered }\end{array}$ & $\begin{array}{l}\text { Nuclear status of } \\
\text { oocytes at end } \\
\text { of culture }\end{array}$ \\
\hline $\begin{array}{l}\text { pro-œstr. .. } \\
\text { pro-œstr. }+\end{array}$ & 12 & none & GV & 103 & 87 & GV or atretic \\
\hline HCG $(1-2 h)$ & 4 & none & GV & 35 & 32 & $\begin{array}{l}30 \mathrm{GV}, 1 \mathrm{Ml}, 1 \text { atre- } \\
\text { tic }\end{array}$ \\
\hline $\begin{array}{l}25 \text { h post- } \\
\text { HCG ..... } \\
25 \text { h post- }\end{array}$ & 1 & none & MI & 12 & 11 & $10 \mathrm{MI}, 1 \mathrm{TI}$ \\
\hline HCG .... & 1 & $\begin{array}{l}\text { dibutyryl } \\
\text { C-AMP }\end{array}$ & MI & 7 & 7 & $1 \mathrm{GV}, 6 \mathrm{MI}$ \\
\hline $\begin{array}{l}25 \mathrm{~h} \text { post- } \\
\mathrm{HCG} . . . \\
25 \mathrm{~h} \text { post- }\end{array}$ & 3 & PGF2 $\alpha$ & PM/MI & 28 & 28 & $3 \mathrm{PM}, 20 \mathrm{MI}, 5 \mathrm{Mll}$ \\
\hline & 3 & PGE2 & $P M / G V$ & 11 & 11 & $5 \mathrm{GV}, 2 \mathrm{PM}, 4 \mathrm{MI}$ \\
\hline œstrus ... & 4 & $\begin{array}{l}\text { prolactin } \\
\text { antiserum }\end{array}$ & GV/PM & 28 & 26 & $\begin{array}{l}12 \mathrm{GV}, 4 \mathrm{PM}, 4 \mathrm{MI} \text {, } \\
6 \mathrm{MII}\end{array}$ \\
\hline $\begin{array}{c}23 \mathrm{~h} \text { post- } \\
\text { HCG } \ldots . . .\end{array}$ & 1 & $\begin{array}{l}\text { prolactin } \\
\text { antiserum }\end{array}$ & PM & 9 & 9 & $6 \mathrm{MI}, 3 \mathrm{Mll}$ \\
\hline $\begin{array}{l}\text { late pro-ces- } \\
\text { trus ...... }\end{array}$ & 3 & $\begin{array}{l}100 \mu \mathrm{g} \text { FSH } \\
60 \mu \mathrm{g} \text { LH } \\
60 \mu \mathrm{g} \text { OE2 }\end{array}$ & GV & 46 & 44 & $20 \mathrm{GV}, 6 \mathrm{MI}, 18 \mathrm{MII}$ \\
\hline $\begin{array}{c}\text { late pro-œs- } \\
\text { trus } \ldots . . .\end{array}$ & 2 & $\begin{array}{l}30 \mu \mathrm{gSH} \\
10 \mu \mathrm{g} \text { LH } \\
10 \mu \mathrm{g} \text { OE2 }\end{array}$ & GV & 20 & 20 & $19 \mathrm{GV}, 1 \mathrm{MI}$ \\
\hline $\begin{array}{l}\text { late pro-ces- } \\
\text { trus } \ldots . . .\end{array}$ & 1 & $\begin{array}{c}60 \mu g \text { FSH } \\
100 \mu g \text { LH } \\
1 \mu g \text { OE2 }\end{array}$ & $\mathrm{GV} / \mathrm{MI}$ & 10 & 10 & $\begin{array}{l}3 \mathrm{MI}, 1 \mathrm{PM}, 2 \mathrm{GV} \text {, } \\
2 \mathrm{Al}, 2 \mathrm{MII}\end{array}$ \\
\hline $\begin{array}{c}\text { late pro-ces- } \\
\text { trus } \ldots \ldots \ldots\end{array}$ & 1 & $\begin{array}{c}100 \mu g \text { FSH } \\
30 \mu g \text { LH } \\
10 \mu g \text { OE2 }\end{array}$ & GV & 5 & 5 & 2 GV, 2 MI, 1 MII \\
\hline
\end{tabular}

$\mathbf{G V}=$ germinal vesicle stage $; \mathrm{PM}=$ pro-metaphase $; \mathrm{MI}=$ metaphase $\mathrm{I} ; \mathrm{Al}=$ anaphase $\mathrm{I} ; \mathrm{MII}=$ metaphase II.

* Individual follicles measuring 6-10 mm diameter were set up in organ culture within $1 \mathrm{~h}$ of ovariectomy performed on day 20 or 21 of the cestrous cycle. When administered, HCG was always injected in procestrus.

** The method used for organ culture has been described elsewhere (Baker, Hunter and Neal, 1975). Follicles presumed to contain oocytes at the GV stage were cultured for 36-40 h.

*** Oocytes were dissected from the follicles, denuded with hyaluronidase, fixed and cleared in 25 p. 100 acetic alcohol, and stained with 0.5 p. 100 orcein in 45 p. 100 acetic acid. 
Perhaps the most significant change in the composition of human follicular fluid at the time of the " LH-surge » is a significant and sharp decline in the concentration of prolactin (McNatty ef al., 1975). It is therefore noteworthy in the present results that an antiserum to prolactin (table 2), when added to porcine Graafian follicles in organ culture, apparently induced meiotic maturation in the oocyte. It is doubtful that prolactin itself plays the role of an inhibitor of oocyte maturation, or of the action of gonadotrophic hormones, but it might prevent the availability of LH-binding sites or induce the binding to protein of intra-follicular steroids. On the other hand, prolactin may play a purely passive role, its elimination from the follicular compartment normally reflecting a change in the permeability of the basement membrane of the follicle, seemingly induced by LH.

Even if prolactin is not in itself an inhibitor of oocyte maturation, it may be involved in the regulation of the inhibitor substance believed to be produced by the granulosa cells (Tsafriri and Channing, 1975). The inhibitor is said to be produced when the follicle is immature, while another protein (antagonist) which nullifies the effects of the inhibitor is seemingly produced in response to gonadotrophins at their surge levels. This speculation, and the possible involvement of prolactin and/or LH in the control of the process, needs to be investigated further by means of carefully controlled experiments in vivo as well as in organ culture. However, a potential inhibitor has recently been recovered from follicular fluid and this substance appears not to be species specific (Tsafriri, 1978).

$27^{e}$ Congrès infernational des Sciences physiologiques, Symposium " Germ and somatic cell interaction " Paris, 21-23 juillet 1977.

Acknowledgements. - The financial support of the Wellcome Trust (London) and The Ford Foundation (New York) is gratefully acknowledged. We are also grateful to Mrs Anne Rae and Mr R. Nichol for technical assistance, and to Dr F. Cunningham of the University of Reading for providing the prolactin antiserum. Ovine LH and FSH were generously provided by NIAMD while porcine FSH and the prostaglandins were provided by the Upjohn Corporation and Sigma Chemicals Lid.

Résumé. Nous avons passé en revue, chez plusieurs mammifères, les facteurs physiologiques qui gouvernent la maturation de l'ovocyte et, en particulier qui provoquent la reprise de la méïose après la décharge ovulante. La taille du follicule est un facteur limitant très important chez plusieurs espèces, bien que lorsqu'on extrait les ovocytes pour les placer dans différents milieux de culture classique, l'influence du diamètre folliculaire ne semble plus jouer, puisqu'une forte proportion des ovocytes reprennent spontanément leur méïose. Dans les follicules de de Graaf, cultivés dans des conditions variables, les conditions pour la reprise de la méïose chez les rongeurs diffèrent de celles nécessaires pour les animaux domestiques et l'homme. Pour ces derniers, les gonadotropines et aussi des stéroïdes tel que l'estradiol, semblent nécessaires pour provoquer la maturation. II est rappelé la dissociation observée, chez la truie, entre l'ovulation obtenue par l'injection d'HCG au 17 jour du cycle ef la reprise de la méïose qui ne se produit pas à ce moment du cycle quand la teneur en estradiol intrafolliculaire est basse. Le rôle possible de l'estradiol sur les cellules somatiques (ou sur l'ovocyte ?) reste à préciser. Une contribution de la prolactine doit aussi être considérée. 


\section{References}

BAKER T. G., 1971. Oogenesis and ovarian development, 398-437. In BALIN H., GLASSER S. R., Reproductive Biology, Excerpta med., Amsterdam.

BAKER T. G., HUNTER R. H. F., BIGGS J. S. G., 1977. Control of oocyte maturation in mammals, 351-355. In JAMES V. H. T., Endocrinology, Excerpia med. int. Congr. Ser. no 402, Amsterdam.

BAKER T. G., HUNTER R. H. F., NEAL P., 1975. Studies on the maintenance of porcine Graafian follicles in organ culture. Experientia, 31, 133-135.

BAKER T. G., NEAL P., 1972. Gonadotrophin-induced maturation of mouse Graafian follicles in organ culture, 377-396. In BIGGERS J. D., SCHUETZ A. W., Oogenesis, Univ. Park Press, Baltimore.

BAKER T. G., NEAL P., 1974. Organ culture of cortical fragments and Graafian follicles from human ovaries. J. Anat. (Lond.), 117, 361-381.

BIGGS J. S. G., BAKER T. G., HUTCHEON D., 1977. Oestradiol production by human Graafian follicles cultured in vitro. J. Obstet Gynaecol. Brit. Commwlth (in press).

HARMAN S. M., LOUVET J.-P., ROSS G. T., 1975. Interaction of estrogen and gonadotropins on follicular atresia. Endocrinology, 96, 1145-1152.

HAY M. F., MOOR R. M., 1975. Functional and structural relationships in the Graafian follicle population of the sheep ovary. J. Reprod. Fert., 45, 583-593.

HAY, M. F., CRAN D. G., 1978. Differential response of components of Graafian follicles to atresia. Ann. Biol. anim. Bioch. Biophys., 18, 453-460.

HUNTER R. H. F., COOK B., BAKER T. G., 1976. Dissociation of response to injected gonadotropin between the Graafian follicle and oocyte in pigs. Noture, 260, 150-158.

LINDNER H. R., TSAFRIRI A., LIEBERMAN M. E., ZOR U., KOCH Y., BAUMINGER S., BARNEA A., 1974. Gonadotropin action on cultured Graafian follicles : induction of maturation division of the mammalian oocyte and differentiation of the luteal cell. Rec. Progr. Hormone Res., 30, 79-138.

MCNATTY K. P., HUNTER W. M., McNEILLY A. S., 1975. Changes in the concentrations of pituitary and steroid hormones in the follicular fluid of human Graafian follicles throughout the menstrual cycle. J. Endocr., 64, 555-571.

MCNATTY K. P., NEAL P., BAKER T. G., 1976. Effect of prolactin on the production of progesterone by mouse ovaries in vitro. J. Reprod. Fert., 47, 155-156.

MOOR R. M., TROUNSON A. O., 1977. Hormonal and follicular factors affecting maturation of sheep oocytes in vitro and their subsequent developmental capacity. J. Reprod. Fert., 49, $101-109$.

NEAL P., BAKER T. G., 1975. Response of mouse Graafian follicles in organ culture to varying doses of follicle stimulating hormone and luteinizing hormone. J. Endocr., 65, 27-32.

NEAL P., BAKER T. G., MCNATTY K. P., SCARAMUZZI R. J., 1975. Influence of prostaglandins and human chorionic gonadotrophin on progesterone concentration and oocyte maturation in mouse ovarian follicles maintained in organ culture. J. Endocr., 65, 19-26.

NEAL P., BAKER T. G., McNATTY K. P., 1976. Effects of prostaglandin F-2 $\alpha$ and E-2 on the production of progesterone by mouse ovaries in vitro. J. Reprod. Fert., 47, 157-159.

SCHUETZ A. W., 1977. Molecular mechanisms controlling cytoplasmic and nuclear maturation of oocytes. Research in Reproduction, 9, 3-4. IPPF, London.

SCHWARTZ N. B., 1974. The role of FSH and LH and their antibodies on follicle growth and on ovulation. Biol. Reprod., 10, 236-272.

SPEROFF L., VANDE WIELE R. L., 1971. Regulation of the human menstrual cycle. Am. J. Obsiet. Gynecol., 109, 234-247.

SORENSEN R. A., WASSERMAN P. M., 1976. Relationship between growth and meiotic maturation of the mouse oocyte. Dev. Biol., 50, 531-536.

THIBAULT C., GÉRARD M., MENEZO Y., 1975. Aquisition par l'ovocyte de lapine et de veau du facteur de condensation du noyau du spermatozoïde fécondant (MPGF). Ann. Biol. anim. Bioch. Biophys., 15, 705-714.

TSAFRIRI A., 1978. Inhibition of nuclear maturation of isolated rat oocytes by follicular constituents. Ann. Biol. anim. Bioch. Biophys., 18, 523-528. 
TSAFRIRI A., CHANNING C. P., 1975. An inhibitory influence of granulosa cells and follicular fluid upon porcine oocyłe meiosis in vitro. Endocrinology, 96, 922-927.

YANG W. H., PAPKOFF H., 1973. Effect of desialylation on ovulation-inducing activity of ovine interstitial cell-stimulating hormone, ovine follicle-stimulating hormone, pregnant mare's serum gonadotropin, and human chorionic gonadotropin in the hamster. Fert. Steril., 24, 633-639.

ZUCKERMAN S., BAKER T. G., 1977. The development of the ovary and the process of oogenesis. In ZUCKERMAN S., The Ovary 2nd ed., vol. 1, chapter 2, 41-112. Acad. Press, New York. 